\title{
Rubén Darío y el origen de la modernidad poética en Hispanoamérica.
}

Víctor Ruiz Universidad Nacional Autónoma de Nicaragua, Managua victor.ruiz@unan.edu.ni https://orcid.org/0000-0001-7389-

9932

(C) UNAN-Managua

Recibido: mayo 2017

Aprobado: junio 2017

En su libro Celebración al Modernismo Saúl Yurkievich afirma que la Vanguardia, en su afán por imponer un presente vertiginoso, impulsado hacia el futuro, borró todo legado con el pasado inmediato. Los vanguardistas renegaron categóricamente de todas las escuelas anteriores a ellos, "sin vislumbrar, como en antas revoluciones, que todos sus propósitos y logro habían germinado poco antes". En pocas palabras, el crítico argentino confirma lo que Octavio Paz en Los Hijos de Limo llamó la tradición de la ruptura, ese vaivén de fracturas, interrupciones, cambios y rebeliones que se suceden de una generación a otra. Según Paz nuestra tradición está hecha de interrupciones y cada ruptura con ella es un regreso al pasado, es decir, un regreso a la tradición: la tradición de la ruptura.

Hoy por hoy, lo afirmado por Yurkievich es una verdad ineludible: el Modernismo, al igual que los jóvenes vanguardistas, se propuso recobrar y restituir a la palabra su libertad para evocar, conjurar y construir realidades verbales; con la misma avidez con la que irrumpe esa generación de idólatras de la modernidad que son Darío, Reissig y Lugones, también irrumpe la generación de Vallejo, Huidobro y Neruda. Ambos grupos se propusieron dinamitar el lenguaje para socavar y transgredir los convencionalismos del mundo factible. Entonces, paradójicamente, la negación de los vanguardistas hispanoamericanos es una afirmación y un regreso a las fuentes de la modernidad poética, modernidad que tiene su origen en ese movimiento iniciado por Rubén Darío.

El modernismo es el punto en que convergen tanto la tradición romántica como la vanguardista. Entendiendo por tradición romántica a ese movimiento que tiene sus primeras manifestaciones en la poesía inglesa y germana, y llega a su clímax en los experimentos poéticos de Baudelaire, Rimbaud y Mallarmé. Cosmopolitismo, exotismo y locura; exaltación de lo irracional y la desmesura; transgresión y transmutación del lenguaje poético: la eterna dicotomía entre prosa y verso se anula, las fronteras entre los géneros se deshacen; son algunos de los elementos románticos que llegan a las vanguardias a través del modernismo. En palabras de Yurkievich, los modernistas "van a preparar a la joven poesía del siglo el terreno para el ejercicio expedito de las libertades textuales"

El modernismo es el primer movimiento poético en Hispanoamérica que constituye una visión y una estética, antes de él, la poesía en lengua española agonizaba entre la exaltación del patetismo y la golosinería verbal; encerrados en sí mismos, los poetas hispanoamericanos de finales del siglo XIX se empeñaban en mantener con vida a un idioma que con la muerte de Bécquer y Castro había dado sus últimas señales vida. Le corresponderá entonces al Modernismo, y sobre todo a un poeta: Rubén Darío, oxigenar, reanimar y rejuvenecer el idioma, flexibilizar y enriquecer un lenguaje. 
Darío y los modernistas serán los primeros en fijar el rumbo de la poesía hispanoamericana no hacia el viejo y desgastado león español, sino hacia la nueva cuna de la cultura occidental: París. Parnasianos y simbolistas, Leconte de Lisle y Charles Baudelaire, serán los paradigmas poéticos de los nuevos escritores latinoamericanos.

De los primeros: el arte por el arte, la pura belleza corporal de la palabra; la despersonalización creadora: el poeta niega la preponderancia de la vida en el arte y, por tanto, las experiencias del autor, los sentimientos personales, las desdichas, la cotidianidad, lo social serán vanos pretextos para poner en juego un mecanismo textual que tenía como único fin la elaboración de un artefacto: el poema. Del simbolismo, los modernistas retomarán la búsqueda de la analogía universal, las correspondencias entre el mundo sensible y el paisaje espiritual del poeta: cada palabra es un símbolo porque evoca una realidad más allá de los sentidos.

En efecto, será en la obra de Darío, nos recuerda Jean Franco, en la que confluirán todas las tendencias antagónicas del modernismo: desde el parnasianismo ortodoxo del arte por el arte, hasta el simbolismo de una lírica hermética y sugerente; desde un paganismo que desacraliza y glorifica los pecados de la carne, hasta una auténtica expresión religiosa; desde una negación al falso nacionalismo, hasta la exaltación al ejército de las naciones argentinas y chilenas; serán estas contradicciones, esta afirmación y negación de una realidad compleja y cambiante, las que darán a la poesía de Darío esa fuerza para mutar, mudar y cambiar de un estilo a otro. "Su poesía refleja la inquietud de su vida", nos declaraba Jean Franco.

Cada uno de sus libros reflejará esa capacidad de adoptar, asimilar y transformar las influencias literarias: en Azul...(1888), fusionará lo mejor de la tradición española con el torrente verbal patriótico de Víctor Hugo; en Prosas Profanas (1896), simbolismo y parnasianismo, erotismo y cristianismo, Dios y Luzbel, amalgamados, derrumbarán toda una tradición poética e impondrán una nueva sensibilidad, confirmando así el papel fundador que Darío ocupará en la poesía modernista; en Cantos de Vida y Esperanza (1905), más viejo y cansado, pero sabio y vigoroso, evocará la voz del demócrata Walt Whitman para llamar a la unión de lo vigores dispersos de Hispanoamérica; invocará al melancólico Francisco de Quevedo en sus poemas nocturnos y escatológicos. Contagio textual por imitación, pero también innovación, afán por renovar y reinventar nuevas formas de expresión, nuevos ritmos, nuevas imágenes. La poesía de Darío nos permitirá vislumbrar más allá de nuestras fronteras, su poesía reflejará la sed de espacio y las ansias por conocer y conquistar otros territorios.

Como vemos, ese afán renovador, esa aventura textual suicida de los vanguardistas hispanoamericanos tiene su punto de partida en el Modernismo. Verso libre, prosa poética, metáforas insólitas serán recursos que también los poetas modernistas utilizarán en sus composiciones verbales. Sin el modernismo, la poesía en lengua española jamás hubiera alcanzado esa libertad con la que Huidobro exalta el poder creativo de la palabra. Así, todo estudio sobre un poeta hispanoamericano, y sobre todo un poeta representativo de una Generación tan importante en Nicaragua y Latinoamérica como es la del 40, debe obligatoriamente comprender una referencia al modernismo y su fundador, Rubén Darío. 